\title{
Effect of neuromedin $U$ on allergic airway inflammation in an asthma model (Review)
}

\author{
XIAOJIE REN ${ }^{1,2}$, FANG DONG $^{1,2}$, YUERONG ZHUANG ${ }^{1,2}$, YONG WANG ${ }^{1,2}$ and WUHUA MA ${ }^{1,2}$ \\ ${ }^{1}$ Guangzhou University of Chinese Medicine; ${ }^{2}$ Department of Anaesthesiology, \\ The First Affiliated Hospital of Guangzhou University of Chinese Medicine, \\ Guangzhou, Guangdong 510405, P.R. China
}

Received February 19, 2019; Accepted November 14, 2019

DOI: $10.3892 /$ etm.2019.8283

\begin{abstract}
Asthma is a major inflammatory airway disease with high incidence and mortality rates. The Global Initiative for Asthma released a report called 'The Global Burden of Asthma' in 2004. However, the specific pathogenesis of asthma remains unclear. An increasing number of studies have demonstrated that neuromedin $\mathrm{U}$ (NMU) plays a pleiotropic role in the pathogenesis of asthma. NMU is a highly structurally conserved neuropeptide that was first purified from porcine spinal cord and named for its contractile effect on the rat uterus. NMU amplifies type 2 innate lymphoid cell (ILC2)-driven allergic lung inflammation. The NMU receptors (NMURs), designated as NMUR1 and NMUR2, belong to the G protein-coupled receptor family. NMUR1 has also been found in immune cells, including ILC2s, mast cells and eosinophils. In view of the important roles of NMU in the pathogenesis of asthma, the present review evaluates the potential mechanisms underlying the impact of NMU on asthma and its association with asthma therapy.
\end{abstract}

Correspondence to: Professor Yong Wang or Professor Wuhua Ma, Department of Anaesthesiology, The First Affiliated Hospital of Guangzhou University of Chinese Medicine, 12 Jichang Road, Guangzhou, Guangdong 510405, P.R. China

E-mail: yongwang@outlook.com

E-mail: gzmwh@aliyun.com

Abbreviations: Areg, amphiregulin; CysLTs, cysteinyl leukotrienes; CGRP, calcitonin gene-related peptide; DAG, diacylglycerol; DC, dendritic cell; ECM, extracellular matrix; ERK, extracellular signal-regulated kinase; FceRI, Fc epsilon receptor I; GPCR, G protein-coupled receptor; HDM, house dust mites; IL, interleukin; ILC2s, type 2 innate lymphoid cells; IP3, inositol 1,4,5-trisphosphate; KO, knockout; NFAT, nuclear factor of activated $\mathrm{T}$ cells; NMU, neuromedin U; NMUR, neuromedin $\mathrm{U}$ receptor; PGD2, prostaglandin D2; PLC, phospholipase C; Th, helper T cell; TSLP, thymic stromal lymphopoietin

Key words: allergy, asthma, type 2 innate lymphoid cells, neuromedin $\mathrm{U}$, mast cells, eosinophils, neuroimmunity

\section{Contents}

1. Introduction

2. Overview of asthma

3. Biology of neuromedin $\mathrm{U}$

4. NMU acts as a multifunctional neuropeptide in the pathogenesis of asthma

5. Clinical implications of NMU involvement in asthma

6. Conclusion

\section{Introduction}

Asthma is a heterogeneous disease that is usually characterized by chronic airway inflammation with airway hyper-responsiveness, airway remodelling and disordered mucosal immunity (1-3). Most asthma-associated deaths occur in low- and low-middle-income countries. According to the latest World Health Organization estimates released in December 2016, approximately 235 million individuals currently suffer from asthma, and 383,000 deaths occurred due to asthma in 2015 (4). The strongest risk factors for developing asthma are exposure to inhaled substances and particles, such as pollen and house dust mites (HDM), which may provoke allergic reactions or irritate the airways $(5,6)$. Patients with asthma suffer recurrent episodes of wheezing, coughing, chest tightness and shortness of breath. These episodes are usually associated with airflow obstruction within the lung, which is often reversible either spontaneously or with treatment (7). Additionally, the specific pathogenesis of asthma remains unclear. Therefore, the investigation of potential molecular mechanisms will improve our understanding of the pathogenesis of asthma and help us to identify new effective therapeutic targets.

Neuromedin U (NMU) is a multifunctional neuropeptide with pleiotropic effects, including the mediation of intestinal peristalsis and the modulation of the sense of satiety, body weight, circadian oscillation, bone formation, insulin production, cancer development, energy balance and metabolism (8-12). However, these effects will not be addressed in the present review. Recently, reports have demonstrated that the neuropeptide NMU enhances ILC2-driven allergic lung inflammation (13-15). Therefore, the effect of 
NMU on the pathogenesis of asthma will be evaluated in the present review.

\section{Overview of asthma}

Asthma is an airway disease and is characterized by four treatable traits: Airflow limitation, altered cough reflex sensitivity, airway infection and airway inflammation $(1,16)$ (Table I). Airflow limitation is caused by several factors, including the sensitization of airway nerves, the accumulation of mast cells, the repeated obstruction of airway smooth muscle, inflammatory mural oedema, the decreased production of bronchoprotective factors and structural changes to the airway $(17,18)$. Airway hyper-responsiveness is another important factor in the development of asthma and is a result of an imbalance in the autonomic nervous system. It involves various inflammatory cells, mediators and cytokines, damage to the epithelial airway, and the exposure of the subepithelial nerve terminals (19). Thirdly, viral infections aggravate airway inflammation in asthma and can even lead to asthma attacks (20). Finally, airway inflammation is heterogeneous among asthma patients. Eosinophilic airway inflammation is the predominant type of granulocytic inflammation because it is recognizable and treatable (21). In patients with eosinophilic asthma, there are two different pathogenic pathways (22). In allergic eosinophilic airway inflammation, specialized dendritic cells present allergens to steer the differentiation of naive $\mathrm{T}$ lymphocytes towards the formation of Th2 cells, which produce cytokines such as interleukin-4 (IL-4), IL-5, IL-9 and IL-13 that result in IgE switching in B cells $(23,24)$. The released $\operatorname{IgE}$ molecules bind to the Fc epsilon receptor I (FceRI) on mast cell surfaces (25). Exposure to allergens and the cross-linking of receptors by allergens, which bind to high-affinity $\operatorname{IgE}$ result in mast cell degranulation (26). Type 2 innate lymphoid cells (ILC2s) are activated by cysteinyl leukotrienes (CysLTs) and prostaglandin D2 (PGD2) secreted by activated mast cells (27). Once activated, ILC2s rapidly expand and secrete large amounts of IL-5 and IL-13. ILC2s contribute to allergic airway inflammation by directly interacting with Th2 cells to promote the release of cytokines, mucus production and airway eosinophilia (28-30). In nonallergic eosinophilic asthma, air pollutants and pathogens induce the release of epithelium-derived and macrophage-derived cytokines, including IL-33, IL-25, TSLP and IL-1 $\beta$, which activate ILC2s in an antigen-independent manner via their respective receptors (Fig. 1) (31,32). It was previously shown that IL-13 released by ILC2 disrupts the bronchial barrier integrity of the airway epithelium in asthmatic patients, therefore maintaining type 2 inflammation in the airways (33). In summary, the role of ILC2s in airway epithelium has received more attention.

In the treatment of asthma, inhaled glucocorticosteroids are currently the most effective anti-inflammatory medications for the therapy of persistent asthma. Their efficacy in decreasing airway hyper-responsiveness has been demonstrated, which decreases asthma symptoms and controls airway inflammation (34). Additionally, long-acting inhaled $\beta 2$-agonists are more effective when combined with inhaled glucocorticosteroids (35). However, long-term exposure to high doses of inhaled glucocorticosteroids leads to adrenal suppression, easy bruising and decreased bone mineral density (36-38). The key role of IL-5 in eosinophilic airway inflammation make it a crucial drug target, which has driven the clinical development of two monoclonal antibodies against IL-5, reslizumab and mepolizumab (39). Nevertheless, these antibodies are ineffective for non-phenotyped patients with persistent asthma who have already received treatment with inhaled corticosteroids (Table I) (22).

Asthma is an inflammatory airway disease involving a variety of cells and cytokines. Due to the phenotypic heterogeneity of asthma, its pathogenesis is complex; the treatable traits are not separate, but are rather interrelated. For this reason, airway disease emerges as an intractable disease, without the development of novel therapies. NMU acts as a multifunctional neuropeptide in allergic responses. In the following sections, the discovery, distribution and function of NMU are to be discussed. Furthermore, the role of NMU in allergic airway inflammation and its potential for clinical application will be discussed.

\section{Biology of neuromedin $U$}

NMU, which was first isolated from porcine spinal cord and named for its potent contractile effect on the rat uterus in 1985 , is a highly conserved peptide secreted by cholinergic neurons (40). NMU was found in rabbits, dogs, frogs and chickens; a 23-amino-acid version was identified in rats, and nonapeptides were detected in guinea pigs and chickens (41-43). NMU is therefore widely conserved throughout the animal kingdom and shows almost complete conservation of its amidated $\mathrm{C}$-terminal pentapeptide, indicating that there is a strong evolutionary pressure to conserve this peptide. NMU also has widespread distribution in the peripheral and central nervous system $(9,44)$. NMU-like immunoreactivity (NMU-LI) protein and mRNA are distributed in the stomach, ileum, spleen, pancreas, heart, lung, kidney, prostate, pituitary gland, adipose tissue, bone, bone marrow and lymphocytes in humans $(45,46)$. NMU-LI is also widely distributed in the central nervous system, including the cingulate gyrus, thalamus, locus coeruleus, medulla oblongata, hypothalamus, substantia nigra and medial frontal gyrus in humans $(45,46)$. Due to the high affinity of NMU and the saturable and specific binding sites for NMU-23 in rats, NMU has been previously characterized as a cognate ligand for the designated 'orphan' class A G-protein-coupled receptors (GPCRs) (47). Two different receptors exist for NMU, termed NMUR1 (also known as GPR66 and FM-3) and NMUR2 (also known as TGR-1 and FM-4), which are encoded by genes located in human chromosomes 2 and 5, respectively (48-50). NMUR1 is mainly expressed in peripheral tissues, such as the intestine, pancreas, uterus, lung and kidney. NMUR2 is predominantly found in specific regions of the central nervous system, including the spinal cord, dorsal root ganglia and medulla oblongata (51). In the rat spinal cord, NMU-like immunoreactivity protein levels are greater in the dorsal than in the ventral horn, suggesting a sensory role for NMU (41). More recently, using chimeric $\mathrm{G}$ proteins, it was demonstrated that NMUR1 primarily signals through the Gq/11 proteins, whereas NMUR2 signals through the Gi proteins $(50,52,53)$. Moreover, NMU mRNA has been detected in antigen-presenting cells, 
Table I. Treatable pulmonary traits in asthma.

\begin{tabular}{|c|c|c|}
\hline Treatable traits & Diagnosis & Treatments \\
\hline Airflow restriction & FEV1/FVC $<$ normal lower limit & \\
\hline $\begin{array}{l}\text { Airway smooth muscle } \\
\text { contraction }\end{array}$ & $\begin{array}{l}\text { Bronchodilator reversibility, peak expi } \\
\text { ratory flow variability, positive } \mathrm{PC}_{20}\end{array}$ & $\begin{array}{l}\beta_{2} \text {-agonists (short-acting and long-acting), } \\
\text { muscarinic antagonists, bronchial thermoplasty }\end{array}$ \\
\hline Airway mucosal oedema & $\begin{array}{l}\text { Chest computed tomography, spirometry- } \\
\text { induced bronchoconstriction }\end{array}$ & $\begin{array}{l}\text { Inhaled corticosteroids. oral corticosteroids, } \\
\text { anti-interleukin-5, }-13,-4\end{array}$ \\
\hline $\begin{array}{l}\text { Altered cough reflex } \\
\text { sensitivity }\end{array}$ & $\begin{array}{l}\text { Heightened capsaicin reflex sensitivity, } \\
\text { Increased cough counts, cough } \\
\text { questionnaire }\end{array}$ & $\begin{array}{l}\text { Speech and language therapy, } \mathrm{P} 2 \mathrm{X} 3 \text { antagonist } \\
\text { gabapentin, inhaled corticosteroids, oral corti } \\
\text { costeroids, cessation of treatment with ACE } \\
\text { inhibitors }\end{array}$ \\
\hline Airway infection & Sputum culture, quantitative PCR & $\begin{array}{l}\text { Antibiotics, long-term low-dose macrolides, } \\
\text { inhaled interferon } \beta \text {, influenza vaccination, } \\
\text { Antifungal drugs }\end{array}$ \\
\hline $\begin{array}{l}\text { Eosinophilic airway } \\
\text { inflammation }\end{array}$ & $\begin{array}{l}\text { Sputum eosinophils, Blood eosinophils, } \\
\text { FeNO }\end{array}$ & $\begin{array}{l}\text { Inhaled corticosteroids, oral corticosteroids, } \\
\text { leukotriene receptor antagonists, anti-IgE, } \\
\text { anti-interleukin-5, }-13,-4\end{array}$ \\
\hline
\end{tabular}

Adapted from Pavord et al (1). FEV1/FVC, forced expiratory volume in $1 \mathrm{sec} /$ forced volume vital capacity ratio; ACE, angiotensin converting enzyme; FeNO, fraction of exhaled nitric oxide; $\mathrm{PC}_{20}$, provocative concentration causing a $20 \%$ fall in FEV1.

particularly monocytes and dendritic cells, and NMUR1 mRNA was detected in T cells and natural killer cells $(54,55)$. Therefore, NMU has the potential to serve as a target for the treatment of asthma.

Thus, NMU is a multifunctional neuropeptide with several roles in different cells and tissue types, which relays signals to the central nervous system (CNS) to stimulate organs. NMU also affects cells directly, by increasing cell proliferation and migration, and inducing the release of hormones and autocrine/paracrine factors. These functions are mostly mediated via the NMUR1 and NMUR2 receptors, although other alternative receptors have been described. It is also possible that NMU may also elicit its effects by binding and signalling through unknown receptors. Furthermore, NMU may also serve as an ideal target for the treatment of certain disorders, although its multiple roles should be taken into consideration when inhibiting its functions for therapeutic purposes (10).

\section{NMU acts as a multifunctional neuropeptide in the pathogenesis of asthma}

$N M U$ and ILC2s. ILC2s have recently been identified as effector cells that are key early regulators of immune responses in airway barrier surfaces (33). ILC2s are activated by cell-derived exogenous cytokines, such as IL-25, IL-33 and thymic stromal lymphopoietin (TSLP). Activated ILC2s produce type 2 cytokines, such as IL-5 and IL-13, to initiate allergic inflammation at mucosal surfaces $(28,56)$. However, the specific molecular pathways that modulate the response of ILC2s to alarmins such as IL-25, IL-33 and TSLP remain unclear (29). Notably, NMUR1 is largely specific to ILC2s, according to single-cell RNA sequencing and flow cytometry (13). Moreover, it is highly expressed in ILC2s at baseline and following the induction of airway inflammation with HDM, in contrast with its expression in other lung-resident cell populations. Furthermore, NMU expands IL-25-driven inflammation. IL-25 combined with NMU led to increased expression of IL-5 and IL-13 in the lung and bronchoalveolar lavage fluid, whereas IL-25 alone only modestly increased their expression. NMU combined with IL-25 alters a non-pathologic dose of IL-25 into a pathogenic dose. However, the number of $\mathrm{ST}^{+}{ }^{+}$ILCs following HDM challenge was decreased in NMU-knockout mice compared with the number in wild-type mice, which indicates that NMU promotes ILC activation and effector function. Moreover, in NMUR1-knockout mice, ILC2 frequency was markedly reduced after HDM challenge compared to that induced by $\mathrm{PBS}$, reflecting the effects also observed in wild-type mice (13). In addition, NMUR1-knockout ILC2s demonstrated lower average inflammatory score than wild-type ILC2s following HDM challenge, which is consistent with the fact that NMU-NMUR1 signalling promotes ILC2 responses in vivo (13-15). In regard to the signalling pathway, through which NMU activates ILC2s, it was shown that NMU activates phospholipase $\mathrm{C}$ (PLC), which catalyses the conversion of the phospholipid inositol to diacylglycerol (DAG) and inositol 1,4,5-trisphosphate (IP3). Subsequently, IP3 induces $\mathrm{Ca}^{2+}$ release from intracellular stores (55). Cardoso et al (14) found that NMU triggered extracellular signal-regulated kinase (ERK) phosphorylation and regulated innate type-2 cytokines downstream of a $\mathrm{Ca}^{2+} /$ calcineurin/NFAT cascade, leading to the expression of the type 2 cytokine genes IL-5, IL-13 and amphiregulin (Areg) in ILC2s (Fig. 2), (57). Thus, the neuropeptide NMU can activate NMUR1 in an ILC2-mediated manner, resulting in the uniquely potent and immediate production of innate type 2 cytokines. 
Allergen

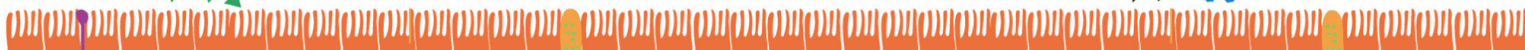

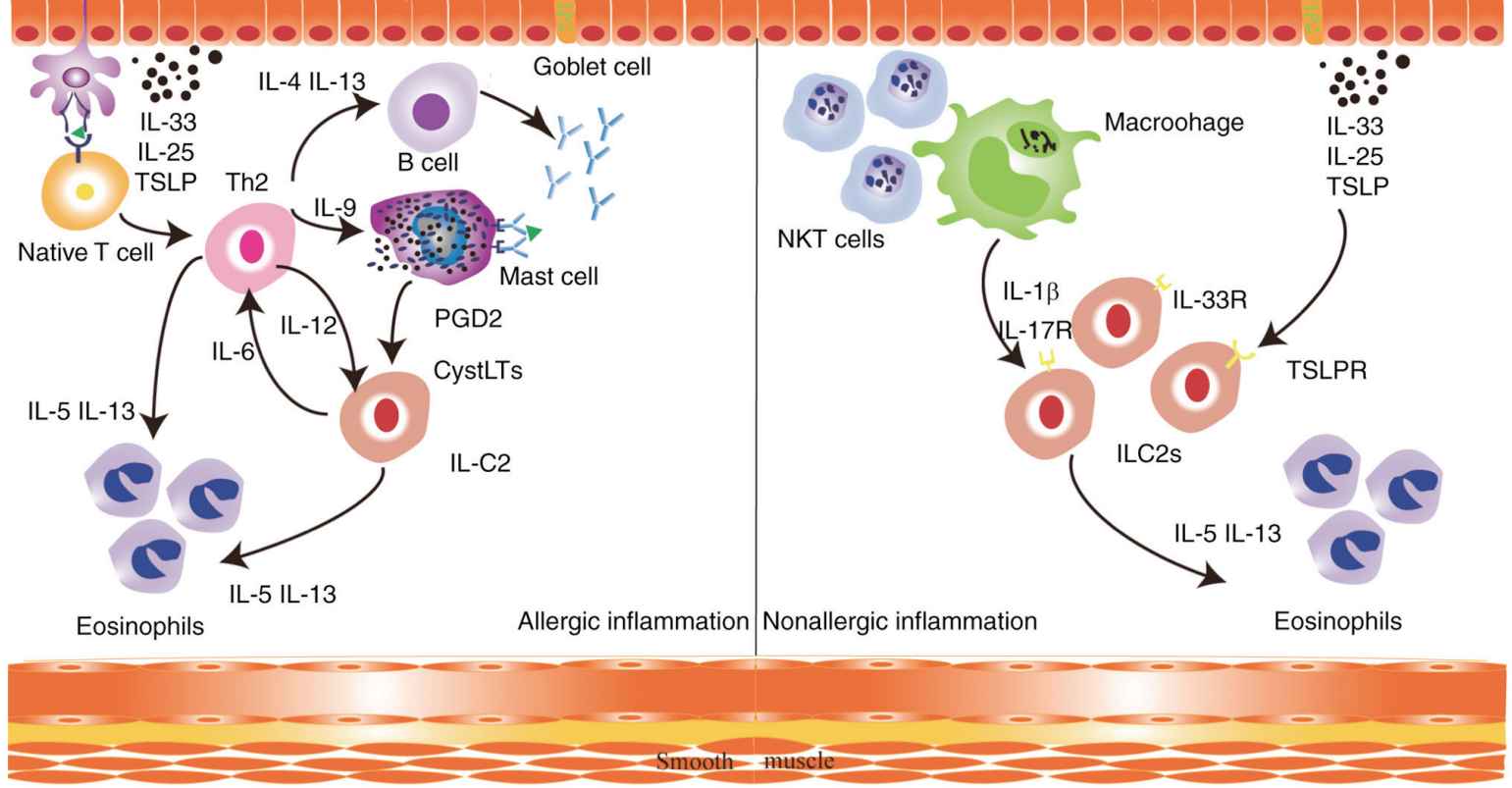

Figure 1. Physiopathology of asthma. In allergic asthma, dendritic cells present allergens to naive T lymphocytes to induce Th2 cells, which produce IL-4 to induce IgE switching in B cells. The released IgE molecules bind to FceR1 on mast cell surfaces. CysLTs and PGD2, which are secreted by activated mast cells, are activators of ILC2s. ILC2s support Th2 cells by inducing a type 2 response, airway eosinophilia and mucous hypersecretion. In non-allergic eosinophilic asthma, air pollutants and pathogens induce the release of epithelium-derived and macrophage-derived cytokines, including IL-33, IL-25, TSLP and IL-1 $\beta$, which activate ILC2s in an antigen-independent manner via their respective receptors. This leads to the secretion of type 2 cytokines by ILC2s, including high amounts of IL-5 and IL-13, which leads to eosinophilia, mucous hypersecretion and airway hyperreactivity. DC, dendritic cells; IL, interleukin; ILC2, type 2 innate lymphoid cell; IL-5R, interleukin 5 receptor; Th, Thelper; CysLTs, cysteinyl leukotrienes; PDG2, prostaglandin D2.

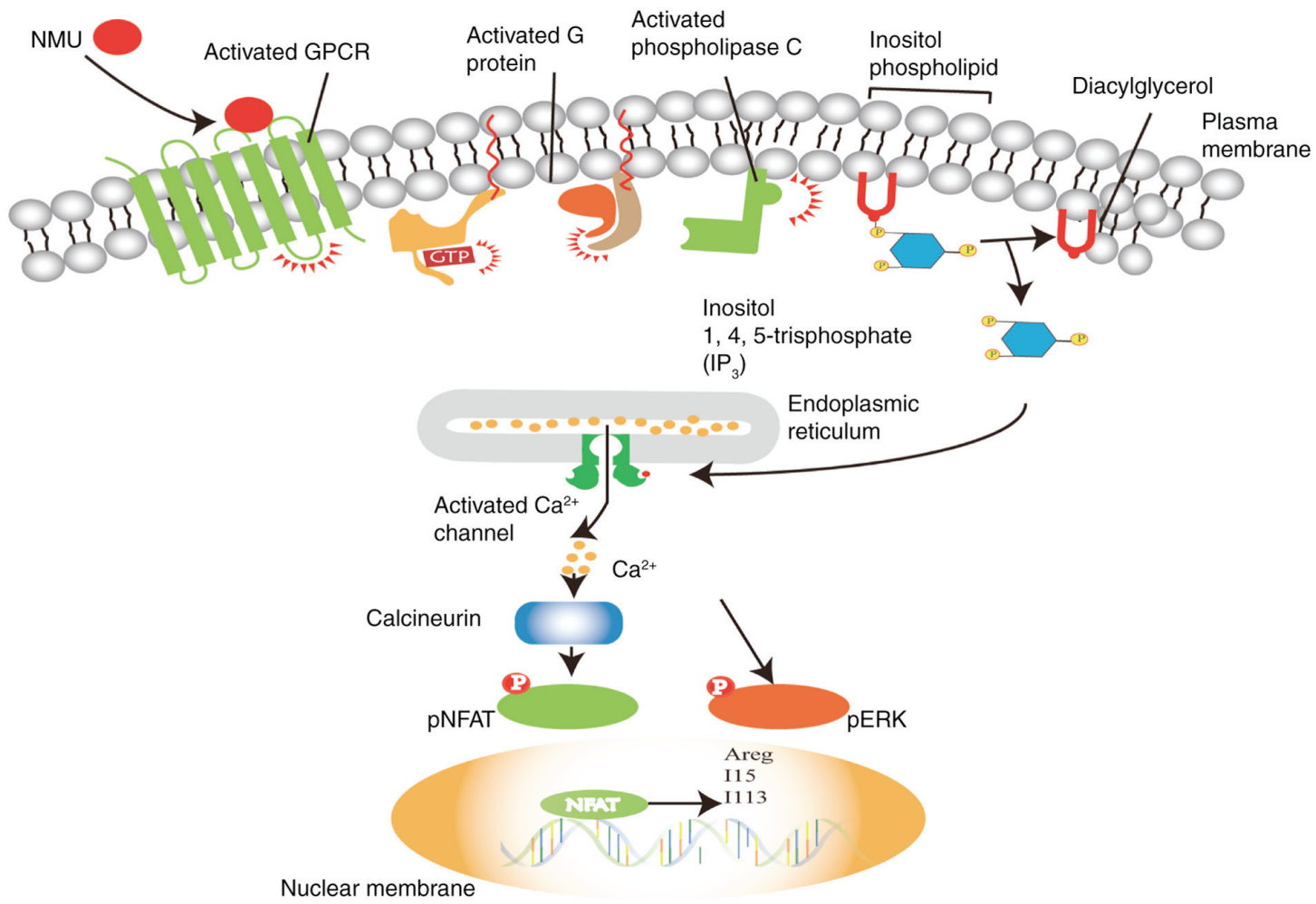

Figure 2. The signalling pathway through which NMU activates ILC2s. NMU activates ILC2s via NMUR1, which is a GPCR. The activated G protein receptor activates PLC, which catalyses the conversion of the phospholipid inositol to DAG and IP3. Subsequently, $\mathrm{IP}_{3}$ elicits $\mathrm{Ca}^{2+}$ release from intracellular stores. The increased $\mathrm{Ca}^{2+}$ influx triggers ERK phosphorylation and activates the $\mathrm{Ca}^{2+}$ calcineurin/NFAT cascade, inducing the increased expression of the type 2 cytokine genes IL-5, IL-13 and Areg. ILC2s, type 2 innate lymphoid cells; GPCR, G protein-coupled receptor; ERK, extracellular signal-regulated kinase; NFAT, nuclear factor of activated T cells; NMU, neuromedin U; NMUR, neuromedin U receptor; p-, phosphorylated; PLC, phospholipase C; DAG, diacylglycerol; $\mathrm{IP}_{3}$, inositol 1,4,5-trisphosphate. 
NMU interacts with mast cells. Mast cells are important participants in the early stage of allergic inflammation and are derived from haematopoietic stem cells. Mast cells affect intercellular communication during inflammation by secreting cytokines that contain several mediators (58). In addition, the severity of airway hyperresponsiveness was strongly correlated with mast cell activation (59). IgE binds to FceRI on mast cells and is crosslinked with specific antigens on the cell surface, which can induce mast cell degranulation and the synthesis of chemokines and cytokines (60). Specifically, mast cells proximal to nerve fibres contain, secrete and respond to several neuropeptides (61). NMUR1 is also highly expressed in mast cells. NMU combines with NMUR1, resulting in mast cell degranulation and the subsequent release of preformed mediators, most notably histamine and chemokines, which leads to early-phase inflammation characterized by vasodilation, extravasation, edema and smooth muscle contraction. Neutrophils also aggregate at reaction sites as a result of the cytokines released by mast cells. The levels of NMU-induced $\mathrm{Ca}^{2+}$ release and mast cell degranulation are nearly comparable with those induced by $\operatorname{IgE}$ receptor cross-linking. In contrast, the subsequent infiltration of neutrophils is completely inhibited in NMU-deficient mice (62). NMU activates mast cell-mediated inflammation; therefore, NMU receptor antagonists could be novel targets for the pharmacological inhibition of mast cell-mediated inflammatory diseases.

NMU contributes to the accumulation of eosinophils. The activation of mast cells by NMU at an early stage might trigger airway inflammation and the release of eosinophilic chemotactic factors, which attract activated eosinophils during allergen exposure and lead to progressive allergic inflammation $(63,64)$. NMUR1 is also expressed in a mouse eosinophil cell line. NMU elevates intracellular $\mathrm{Ca}^{2+}$ levels and ERK phosphorylation and activation, which promotes cell adhesion to components of the extracellular matrix (ECM), and eotaxins contribute to eosinophil accumulation. Inflammatory cells adhere and interact with components of the blood cell wall and the ECM, which aids their ability to extravasate and migrate into inflamed sites (65). NMU acts directly on eosinophils to play an important role in cell activation, adhesion and migration. On the contrary, it was observed that the absence of $\mathrm{Gq}$ signalling in Gq-deficient mice blocked the accumulation of eosinophils in the lungs, following an allergic challenge $(15,66)$. NMU directly acts on eosinophils to induce cell adhesion to fibronectin and collagen type I. Additionally, eosinophil chemotaxis is induced by NMU at high concentration that is comparable to that induced by eotaxin, which is also known to be involved in integrin activation and the adhesion of eosinophils. Thus, NMU is an important mediator of eosinophil-mediated inflammation, and a potential therapeutic target for bronchial asthma/eosinophil-mediated inflammatory diseases (67). To date, only limited data have been obtained regarding the possible importance of NMU and eosinophils. Therefore, the association between NMU and eosinophils requires further study.

Role of NMU in neuroimmunity. Evolution has generated multiple mechanisms to defend against external and internal sources of danger. For example, the immune system eliminates various threats through a variety of immune cells and antibodies. The nervous system promptly inputs information into the CNS and produces complex defence behaviours. The immune system and the nervous system cooperate with each other to defend against danger. In this, they share a common 'language' comprised of cytokines, receptors, and neuropeptides, which enable mutual communication (68). Immune cells are found in close proximity to the nerve terminal processes in the mucosal surfaces of the airways, which are then poised for interaction (23). The lung is extensively innervated via sensory fibres, most of which express markers of nociceptors (69). Asthmatic patients have a denser network of these fibres around small airways and a low threshold for their activation in response to airborne irritants $(70,71)$. This indicates the excess activity of peptidergic sensory fibres. Upon exposure to allergens, nociceptor peripheral terminals release neuropeptides, such as substance $\mathrm{P}$ and calcitonin gene-related peptide (CGRP), resulting in neuroimmunity $(68,72,73)$. Furthermore, NMU has been found in the spinal cord, dorsal root ganglia and medulla oblongata via radioimmunoassays and immunohistochemistry $(41,74)$. The distribution of NMU is consistent with that of neurons involved in nociception. One of the physiological roles of NMU may be its involvement in nociception (75). Neurons that secret NMU can be found in the ventromedial hypothalamic regions and in some nuclei of the caudal brainstem regions, which are involved in nociceptive transmission and pain modulation (44,45,76). NMU has been demonstrated to markedly and selectively enhance the excitability of nociceptive neurons in spinal dorsal horns in a dose-dependent manner (77). Hyperactivity of nociceptive dorsal horn neurons induced by NMU could mediate pain-associated behavioural changes and several neuroendocrine functions (49). This expression pattern of NMUR2 mRNA corroborated with the hypothesis that its ligand, NMU, is a sensory transmitter/modulator (77). Compared with the wild-type mice, the nociceptive reflexes were decreased in the NMU KO mice, indicating that endogenous NMU may play an important role in reflexes and in adaptation to environmental stimuli (78). The mRNA expression NMU is increased in the spinal cord but not in the hypothalamus following a pain stimulus, suggesting that pain may stimulate the synthesis of NMU. Thus, NMU is involved in nociceptive reflexes (78). Nociceptor activation upon allergen exposure is a very early event in the development of inflammation. Appreciation of the immune and nervous systems as part of a holistic, coordinated defence system provides new insights into inflammation and exciting opportunities for managing acute and chronic inflammatory diseases (73). In short, these studies suggest that NMU is important for nociceptive reflexes and allergen exposure, although more detailed genetic and mechanistic investigations of NMU and its role in vivo and in vitro are still required.

\section{Clinical implications of NMU involvement in asthma}

In view of the importance of allergic airway inflammation in the clinical manifestations of allergic diseases, it is of note that NMU can induce immune cell-driven inflammation. Upon inhaling pollutants, microbes and glycolipids, the nervous system rapidly processes information and triggers these processes. NMU acts as a mediator between sensory neurons 
and immune cells to potentiate or initiate inflammation. Overall, NMU provides a novel neuroimmune target for the treatment of asthma. At present, there are no investigative reports regarding the development of NMUR subtype-selective antagonists. The natural products EUK2010, EUK2011 and EUK2012 have been identified as NMUR2-specific agonists, and icariin from Herba epimedii has been described as an NMUR2-selective agonist $(79,80)$. Structure-activity relationship study identified the more potent hexapeptide 5d that exhibits NMUR1 agonist activity similar to that of Hnmu (81). Moreover, scientists have discovered two synthetic low molecular weight non-selective NMU receptor agonists (45).

Regarding asthma therapy based on the function of NMU, NMU amplifies allergic airway inflammation in an asthma model. This indicates that NMU might be a meaningful therapeutic target for the treatment of allergic airway inflammation in asthma. For example, ketotifen, as a mast cell membrane stabilizer, can protect mast cell membranes to decrease membrane metamorphosis and the release of allergic inflammation mediators (82). Additionally, butyrate ameliorates allergic airway inflammation by limiting eosinophil trafficking and survival (83). Considering the constant progress in pharmaceutical development and molecular biology, screening for novel molecules that act on targets in the human airway and immune cells will be conducted, leading to new treatments for asthma.

\section{Conclusion}

In the context of the complexity and intricacy of airway inflammation, NMU acts as a multifunctional neuropeptide in the pathogenesis of asthma. An understanding of the function of NMU aids in improving the understanding of the mechanism underlying the pathogenesis of asthma. Considering the constant improvements in organoid culture systems and transcriptomic techniques, NMU receptor antagonists will likely be a novel target for the pharmacological inhibition of asthma in the near future, which may significantly improve the clinical outcomes of patients with asthma. However, the precise regulation of NMU in asthma still requires further study, in order to be used in clinical applications.

\section{Acknowledgements}

Not applicable.

\section{Funding}

This work was supported by grants from the National Natural Science Foundation of China (grant nos. 81673922, 81503663 and 81704167) and the Project of Educational Commission of Guangdong Province of China (grant no. 2018KTSCX037).

\section{Availability of data and materials}

Not applicable.

\section{Authors' contributions}

XR participated in the entire review process and prepared the manuscript. FD and YZ contributed to collecting the relevant literature. YW and WM conceived the review and modified the manuscript. All authors read and approved the final version of the manuscript.

\section{Ethics approval and consent to participate}

Not applicable.

\section{Patient consent for publication}

Not applicable.

\section{Competing interests}

The authors declare that they have no competing interests.

\section{References}

1. Pavord ID, Beasley R, Agusti A, Anderson GP, Bel E, Brusselle G, Cullinan P, Custovic A, Ducharme FM, Fahy JV, et al: After asthma: Redefining airways diseases. Lancet 391: 350-400, 2018.

2. Bateman ED, Hurd SS, Barnes PJ, Bousquet J, Drazen JM, FitzGerald M, Gibson P, Ohta K, O'Byrne P, Pedersen SE, et al: Global strategy for asthma management and prevention: GINA executive summary. Eur Respir J 31: 143-178, 2008.

3. Ray A, Raundhal M, Oriss TB, Ray P and Wenzel SE: Current concepts of severe asthma. J Clin Invest 126: 2394-2403, 2016.

4. Word Health Organiztion (2017). Asthma Fact Sheet. http://www. who.int/mediacentre/factsheets/fs307/en/. Accessed May 26, 2018.

5. McInnes RN, Hernming D, Burgess P, Lyndsay D, Osborne NJ, Skjøth CA, Thomas S and Vardoulakis S: Mapping allergenic pollen vegetation in UK to study environmental exposure and human health. Sci Total Environ 599-600: 483-499, 2017.

6. Stein MM, Hrusch CL, Gozdz J, Igartua C, Pivniouk V, Murray SE, Ledford JG, dos Santos MM, Anderson RL, Metwali N, et al: Innate immunity and asthma risk in amish and hutterite farm children. N Engl J Med 375: 411-421, 2016.

7. Bleecker ER, FitzGerald JM, Chanez P, Papi A, Weinstein SF, Barker P, Sproule S, Gilmartin G, Aurivillius M, Werkström V, et al: Efficacy and safety of benralizumab for patients with severe asthma uncontrolled with high-dosage inhaled corticosteroids and long-acting $\beta_{2}$-agonists (SIROCCO): A randomised, multicentre, placebo-controlled phase 3 trial. Lancet 388: 2115-2127, 2016.

8. Chiu CN, Rihel J, Lee DA, Singh C, Mosser EA, Chen SJ, Sapin V, Pham U, Engle J, Niles BJ, et al: A zebrafish genetic screen identifies neuromedin $U$ as a regulator of sleep/wake states. Neuron 89: 842-856, 2016.

9. Schlegel P, Texada MJ, Miroschnikow A, Schoofs A, Hückesfeld S, Peters M, Schneider-Mizell CM, Lacin H, Li F, Fetter RD, et al: Synaptic transmission parallels neuromodulation in a central food-intake circuit. Elife 5: e16799, 2016.

10. Martinez VG and O'Driscoll L: Neuromedin U: A multifunctional neuropeptide with pleiotropic roles. Clin Chem 61: 471-482, 2015.

11. Lee J, Snyder ER, Liu YH, Gu XY, Wang J, Flowers BM, Kim YJ, Park S, Szot GL, Hruban RH, et al: Reconstituting development of pancreatic intraepithelial neoplasia from primary human pancreas duct cells. Nat Commun 8: 14686, 2017.

12. Alfa RW, Park S, Skelly KR, Poffenberger G, Jain N, Gu X, Kockel L, Wang J, Liu YH, Powers AC and Kim SK: Suppression of insulin production and secretion by a decretin hormone. Cell Metab 21: 323-333, 2015.

13. Wallrapp A, Riesenfeld SJ, Burkett PR, Abdulnour RE, Nyman J, Dionne D, Hofree M, Cuoco MS, Rodman C, Farouq D, et al: The neuropeptide NMU amplifies ILC2-driven allergic lung inflammation. Nature 549: 351-356, 2017.

14. Cardoso V, Chesné J, Ribeiro H, García-Cassani B, Carvalho T, Bouchery T, Shah K, Barbosa-Morais NL, Harris N and Veiga-Fernandes H: Neuronal regulation of type 2 innate lymphoid cells via neuromedin U. Nature 549: 277-281, 2017. 
15. Klose CSN, Mahlakõiv T, Moeller JB, Rankin LC, Flamar AL, Kabata H, Monticelli LA, Moriyama S, Putzel GG, Rakhilin N, et al: The neuropeptide neuromedin U stimulates innate lymphoid cells and type 2 inflammation. Nature 549: 282-286, 2017.

16. Hargreave FE and Nair P: The definition and diagnosis of asthma. Clin Exp Allergy 39: 1652-1658, 2009.

17. O'Reilly R, Ullmann N, Irving S, Bossley CJ, Sonnappa S, Zhu J, Oates T, Banya W, Jeffery PK, Bush A and Saglani S: Increased airway smooth muscle in preschool wheezers who have asthma at school age. J Allergy Clin Immunol 131: 1024-1032, 32.e1-16, 2013.

18. Noble PB, Pascoe CD, Lan B, Ito S, Kistemaker LE, Tatler AL, Pera T, Brook BS, Gosens R and West AR: Airway smooth muscle in asthma: Linking contraction and mechanotransduction to disease pathogenesis and remodelling. Pulm Pharmacol Ther 29: 96-107, 2014 .

19. Nair P, Martin JG, Cockcroft DC, Dolovich M, Lemiere C, Boulet LP and O'Byrne PM: Airway hyperresponsiveness in asthma: Measurement and clinical relevance. J Allergy Clin Immunol Pract 5: 649-659.e2, 2017.

20. Jackson DJ and Johnston SL: The role of viruses in acute exacerbations of asthma. J Allergy Clin Immunol 125: 1178-1187; quiz $1188-1189,2010$

21. Pascoe S, Locantore N, Dransfield MT, Barnes NC and Pavord ID: Blood eosinophil counts, exacerbations, and response to the addition of inhaled fluticasone furoate to vilanterol in patients with chronic obstructive pulmonary disease: A secondary analysis of data from two parallel randomised controlled trials. Lancet Respir Med 3: 435-442, 2015

22. Brusselle GG, Maes T and Bracke KR: Eosinophils in the spotlight: Eosinophilic airway inflammation in nonallergic asthma. Nat Med 19: 977-979, 2013.

23. Veres TZ, Shevchenko M, Krasteva G, Spies E, Prenzler F, Rochlitzer S, Tschernig T, Krug N, Kummer W and Braun A: Dendritic cell-nerve clusters are sites of $\mathrm{T}$ cell proliferation in allergic airway inflammation. Am J Pathol 174: 808-817, 2009.

24. Furuhashi K, Chua YL, Wong KHS, Zhou Q, Lee DCP, Liong KH, Teo GH, Hutchinson PE and Kemeny DM: Priming with high and low respiratory allergen dose induces differential $\mathrm{CD} 4^{+} \mathrm{T}$ helper type 2 cells and $\mathrm{IgE} / \mathrm{IgG1}$ antibody responses in mice. Immunology 151: 227-238, 2017.

25. Suzuki R, Leach S, Liu WH, Ralston E, Scheffel J, Zhang W, Lowell CA and Rivera J: Molecular editing of cellular responses by the high-affinity receptor for IgE. Science 343: 1021-1025, 2014.

26. Cao PP, Zhang YN, Liao B, Ma J, Wang BF, Wang H, Zeng M, Liu WH, Schleimer RP and Liu Z: Increased local IgE production induced by common aeroallergens and phenotypic alteration of mast cells in Chinese eosinophilic, but not non-eosinophilic, chronic rhinosinusitis with nasal polyps. Clin Exp Allergy 44 690-700, 2014.

27. Moretti S, Renga G, Oikonomou V, Galosi C, Pariano M, Iannitti RG, Borghi M,Puccetti M, De Zuani M,Pucillo CE, et al: A mast cell-ILC2-Th9 pathway promotes lung inflammation in cystic fibrosis. Nat Commun 8: 14017, 2017.

28. Serafini N, Vosshenrich CA and Di Santo JP: Transcriptional regulation of innate lymphoid cell fate. Nat Rev Immunol 15 415-428, 2015

29. Licona-Limón P, Kim LK, Palm NW and Flavell RA: TH2, allergy and group 2 innate lymphoid cells. Nat Immunol 14 536-542, 2013

30. Mesnil C, Raulier S, Paulissen G, Xiao X, Birrell MA, Pirottin D, Janss T, Starkl P, Ramery E, Henket M, et al: Lung-resident eosinophils represent a distinct regulatory eosinophil subset. J Clin Invest 126: 3279-3295, 2016.

31. Bal SM, Bernink JH, Nagasawa M, Groot J, Shikhagaie MM, Golebski K, van Drunen CM, Lutter R, Jonkers RE, Hombrink P, et al: IL-1 $\beta$, IL-4 and IL-12 control the fate of group 2 innate lymphoid cells in human airway inflammation in the lungs. Nat Immunol 17: 636-645, 2016.

32. Wenzel SE: Asthma phenotypes: The evolution from clinical to molecular approaches. Nat Med 18: 716-725, 2012.

33. Sugita K, Steer CA, Martinez-Gonzalez I, Altunbulakli C, Morita H, Castro-Giner F, Kubo T, Wawrzyniak P, Ruckert B, Sudo K, et al: Type 2 innate lymphoid cells disrupt bronchia epithelial barrier integrity by targeting tight junctions through IL-13 in asthmatic patients. J Allergy Clin Immunol 141: 300-310.e11, 2018
34. Pauwels RA, Löfdahl CG, Postma DS, Tattersfield AE, O'Byrne P, Barnes PJ and Ullman A: Effect of inhaled formoterol and budesonide on exacerbations of asthma. formoterol and corticosteroids establishing therapy (FACET) international study group. N Engl J Med 337: 1405-1411, 1997.

35. Gibson PG, Powell H and Ducharme FM: Differential effects of maintenance long-acting beta-agonist and inhaled corticosteroid on asthma control and asthma exacerbations. J Allergy Clin Immunol 119: 344-350, 2007

36. Weinstein RS: Clinical practice. Glucocorticoid-induced bone disease. N Engl J Med 365: 62-70, 2011.

37. Mak VH, Melchor R and Spiro SG: Easy bruising as a side-effect of inhaled corticosteroids. Eur Respir J 5: 1068-1074, 1992.

38. Brown PH, Greening AP and Crompton GK: Large volume spacer devices and the influence of high dose beclomethasone dipropionate on hypothalamo-pituitary-adrenal axis function. Thorax 48: 233-238, 1993.

39. Mukherjee M, Aleman Paramo F, Kjarsgaard M, Salter B, Nair G, LaVigne N, Radford K, Sehmi R and Nair P: Weight-adjusted intravenous reslizumab in severe asthma with inadequate response to fixed-dose subcutaneous mepolizumab. Am J Respir Crit Care Med 197: 38-46, 2018.

40. Minamino N, Kangawa K and Matsuo H: Neuromedin U-8 and U-25: Novel uterus stimulating and hypertensive peptides identified in porcine spinal cord. Biochem Biophys Res Commun 130 1078-1085, 1985

41. Domin J, Ghatei MA, Chohan P and Bloom SR: Neuromedin U--a study of its distribution in the rat. Peptides 8: 779-784, 1987.

42. Tanida M, Satomi J, Shen J and Nagai K: Autonomic and cardiovascular effects of central neuromedin U in rats. Physiol Behav 96: 282-288, 2009.

43. Austin C, Lo G, Nandha KA, Meleagros L and Bloom SR: Cloning and characterization of the cDNA encoding the human neuromedin $\mathrm{U}(\mathrm{NmU})$ precursor: $\mathrm{NmU}$ expression in the human gastrointestinal tract. J Mol Endocrinol 14: 157-169, 1995.

44. Gevaert B, Wynendaele E, Stalmans S, Bracke N, D'Hondt M, Smolders I, van Eeckhaut A and De Spiegeleer B: Blood-brain barrier transport kinetics of the neuromedin peptides NMU, NMN, NMB and NT. Neuropharmacology 107: 460-470, 2016.

45. Mitchell JD, Maguire JJ and Davenport AP: Emerging pharmacology and physiology of neuromedin $\mathrm{U}$ and the structurally related peptide neuromedin S. Br J Pharmacol 158: 87-103, 2009.

46. Szekeres PG, Muir AI, Spinage LD, Miller JE, Butler SI, Smith A, Rennie GI, Murdock PR, Fitzgerald LR, Wu H, et al: Neuromedin $U$ is a potent agonist at the orphan $\mathrm{G}$ protein-coupled receptor FM3. J Biol Chem 275: 20247-20250, 2000.

47. Alexander SP, Mathie A and Peters JA: Guide to receptors and channels (GRAC), 3rd edition. Br J Pharmacol 153 (Suppl 2): S1-S209, 2008

48. Hosoya M, Moriya T, Kawamata Y, Ohkubo S, Fujii R, Matsui H, Shintani Y, Fukusumi S, Habata Y, Hinuma S, et al: Identification and functional characterization of a novel subtype of neuromedin U receptor. J Biol Chem 275: 29528-29532, 2000.

49. Fujii R, Hosoya M,Fukusumi S, Kawamata Y,Habata Y,Hinuma S, Onda $\mathrm{H}$, Nishimura $\mathrm{O}$ and Fujino $\mathrm{M}$ : Identification of neuromedin $\mathrm{U}$ as the cognate ligand of the orphan $\mathrm{G}$ protein-coupled receptor FM-3. J Biol Chem 275: 21068-21074, 2000.

50. Howard AD, Wang R, Pong SS, Mellin TN, Strack A, Guan XM, Zeng Z, Williams DL Jr, Feighner SD, Nunes CN, et al: Identification of receptors for neuromedin $U$ and its role in feeding. Nature 406: 70-74, 2000.

51. Kakarala KK and Jamil K: Sequence-structure based phylogeny of GPCR Class A Rhodopsin receptors. Mol Phylogenet Evol 74: 66-96, 2014.

52. Brighton PJ, Szekeres PG, Wise A and Willars GB: Signaling and ligand binding by recombinant neuromedin $U$ receptors: Evidence for dual coupling to Galphaq/11 and Galphai and an irreversible ligand-receptor interaction. Mol Pharmacol 66: 1544-1556, 2004.

53. Hsu SH and Luo CW: Molecular dissection of G protein preference using Gsalpha chimeras reveals novel ligand signaling of GPCRs. Am J Physiol Endocrinol Metab 293: E1021- E1029, 2007.

54. Moriyama M, Matsukawa A, Kudoh S, Takahashi T, Sato T, Kano T, Yoshimura A and Kojima M: The neuropeptide neuromedin U promotes IL-6 production from macrophages and endotoxin shock. Biochem Biophys Res Commun 341: 1149-1154, 2006.

55. Johnson EN, Appelbaum ER, Carpenter DC, Cox RF, Disa J, Foley JJ, Ghosh SK, Naselsky DP, Pullen MA, Sarau HM, et al: Neuromedin U elicits cytokine release in murine Th2-type T cell clone D10.G4.1. J Immunol 173: 7230-7238, 2004. 
56. Cording S, Medvedovic J, Aychek T and Eberl G: Innate lymphoid cells in defense, immunopathology and immunotherapy. Nat Immunol 17: 755-757, 2016.

57. Zhang Y, Jiang D, Zhang Y, Jiang X, Wang F and Tao J: Neuromedin U type 1 receptor stimulation of A-type K+ current requires the $\beta \mathrm{g}$ subunits of Go protein, protein kinase $\mathrm{A}$, and extracellular signal-regulated kinase $1 / 2($ ERK1/2) in sensory neurons. J Biol Chem 287: 18562-18572, 2012.

58. Gaudenzio N, Sibilano R, Marichal T, Starkl P, ReberLL, Cenac N, McNeil BD, Dong XZ, Hernandez JD, Sagi-Eisenberg R, et al: Different activation signals induce distinct mast cell degranulation strategies. J Clin Invest 126: 3981-3998, 2016.

59. Mizutani N, Nabe T and Yoshino S: IgE/antigen-mediated enhancement of $\mathrm{IgE}$ production is a mechanism underlying the exacerbation of airway inflammation and remodelling in mice. Immunology 144: 107-115, 2015.

60. Zhang N, Li H, Jia JH and He MQ: Anti-inflammatory effect of curcumin on mast cell-mediated allergic responses in ovalbumininduced allergic rhinitis mouse. Cell Immunol 298: 88-95, 2015.

61. Tore F and Tuncel N: Mast cells: Target and source of neuropeptides. Curr Pharm Des 15: 3433-3445, 2009.

62. Moriyama M, Sato T, Inoue H, Fukuyama S, Teranishi $H$, Kangawa K, Kano T, Yoshimura A and Kojima M: The neuropeptide neuromedin $\mathrm{U}$ promotes inflammation by direct activation of mast cells. J Exp Med 202: 217-224, 2005.

63. Smith SG, Chen R, Kjarsgaard M, Huang C, Oliveria JP, O'Byrne PM, Gauvreau GM, Boulet LP, Lemiere C, Martin J, et al: Increased numbers of activated group 2 innate lymphoid cells in the airways of patients with severe asthma and persistent airway eosinophilia. J Allergy Clin Immunol 137: 75-86.e8, 2016.

64. Mukherjee M, Bulir DC, Radford K, Kjarsgaard M, Huang CM, Jacobsen EA, Ochkur SI, Catuneanu A, Lamothe-Kipnes H, Mahony J, et al: Sputum autoantibodies in patients with severe eosinophilic asthma. J Allergy Clin Immunol 141: 1269-1279, 2018.

65. Johansson MW: Eosinophil activation status in separate compartments and association with asthma. Front Med (Lausanne) 4: 75, 2017.

66. Borchers MT, Justice PJ, Ansay T, Mancino V, McGarry MP, Crosby J, Simon MI, Lee NA and Lee JJ: Gq signaling is required for allergen-induced pulmonary eosinophilia. J Immunol 168 3543-3549, 2002.

67. Moriyama M, Fukuyama $\mathrm{S}$, Inoue $\mathrm{H}$, Matsumoto $\mathrm{T}$, Sato $\mathrm{T}$, Tanaka K, Kinjyo I, Kano T, Yoshimura A and Kojima M: The neuropeptide neuromedin $\mathrm{U}$ activates eosinophils and is involved in allergen-induced eosinophilia. Am J Physiol Lung Cell Mol Physiol 290: L971-L977, 2006.

68. Talbot S, Foster SL and Woolf CJ: Neuroimmunity: Physiology and pathology. Annu Rev Immunol 34: 421-447, 2016.

69. Ni D, Gu Q, Hu HZ, Gao N, Zhu MX and Lee LY: Thermal sensitivity of isolated vagal pulmonary sensory neurons: Role of transient receptor potential vanilloid receptors. Am J Physiol Regul Integr Comp Physiol 291: R541-R550, 2006.

70. Myers AC, Kajekar R and Undem BJ: Allergic inflammation-induced neuropeptide production in rapidly adapting afferent nerves in guinea pig airways. Am J Physiol Lung Cell Mol Physiol 282: L775-L781, 2002.
71. Canning BJ and Spina D: Sensory nerves and airway irritability. Handb Exp Pharmacol 139-183, 2009.

72. Hoogerwerf WA, Zou L, Shenoy M, Sun D, Micci MA, Lee-Hellmich H, Xiao SY, Winston JH and Pasricha PJ: The proteinase-activated receptor 2 is involved in nociception. J Neurosci 21: 9036-9042, 2001.

73. Talbot S, Abdulnour RE, Burkett PR, Lee S, Cronin SJ, Pascal MA, Laedermann C, Foster SL, Tran JV, Lai N, et al: Silencing nociceptor neurons reduces allergic airway inflammation. Neuron 87: 341-354, 2015.

74. Ballesta J, Carlei F, Bishop AE, Steel JH, Gibson SJ, Fahey M, Hennessey R, Domin J, Bloom SR and Polak JM: Occurrence and developmental pattern of neuromedin U-immunoreactive nerves in the gastrointestinal tract and brain of the rat. Neuroscience 25: 797-816, 1988.

75. Yu XH, Cao CQ, Mennicken F, Puma C, Dray A, O'Donnell D, Ahmad S and Perkins M: Pro-nociceptive effects of neuromedin U in rat. Neuroscience 120: 467-474, 2003.

76. Wall PD and Melzack R: Textbook of Pain. 4th edition. Churchill Livingstone, London, 1999.

77. Cao CQ, Yu XH, Dray A, Filosa A and Perkins MN: A pro-nociceptive role of neuromedin $U$ in adult mice. Pain 104: 609-616, 2003.

78. Nakahara K, Kojima M, Hanada R, Egi Y, Ida T, Miyazato M, Kangawa K and Murakami N: Neuromedin U is involved in nociceptive reflexes and adaptation to environmental stimuli in mice. Biochem Biophys Res Commun 323: 615-620, 2004.

79. Fang L, Zhang M, Li C, Dong S and Hu Y: Chemical genetic analysis reveals the effects of NMU2R on the expression of peptide hormones. Neurosci Lett 404: 148-153, 2006.

80. Zheng X, Hu Y, Liu J and Ouyang K: Screening of active compounds as neuromedin U2 receptor agonist from natural products. Bioorg Med Chem Lett 15: 4531-4535, 2005.

81. Takayama K, Mori K, Sohma Y, Taketa K, Taguchi A, Yakushiji F, Minamino N, Miyazato M, Kangawa K and Hayashi Y: Discovery of potent hexapeptide agonists to human neuromedin U receptor 1 and identification of their serum metabolites. ACS Med Chem Lett 6: 302-307, 2015.

82. Szczeklik A, Czerniawska-Mysik G, Adamek-Guzik T, Woloszynski J and Koterba A: Ketotifen versus sodium cromoglycate in the therapy of allergic (extrinsic) bronchial asthma. Respiration 39 (Suppl 1): S3-S9, 1980.

83. Theiler A, Barnthaler T, Platzer W, Richtig G, Peinhaupt M, Rittchen S, Kargl J, Ulven T, Marsh LM, Marsche G, et al: Butyrate ameliorates allergic airway inflammation by limiting eosinophil trafficking and survival. J Allergy Clin Immunol 144: 764-776, 2019.

(i) $(9)$ This work is licensed under a Creative Commons EY NO ND Attribution-NonCommercial-NoDerivatives 4.0 International (CC BY-NC-ND 4.0) License. 